\title{
Peroral Extrusion of Ventriculoperitoneal Shunt: An Unusual Complication and Review of Literature
}

\author{
Ankit S. Shah ${ }^{1}$ Daljit Singh ${ }^{1}$ Poonam Loomba ${ }^{2}$ Hukum Singh ${ }^{1}$ Amit Mittal ${ }^{1}$ Siddharth Srivastava ${ }^{3}$ \\ ${ }^{1}$ Department of Neurosurgery, G. B. Pant Institute of Post Graduate \\ Medical Education and Research (GIPMER), New Delhi, India \\ 2 Department of Microbiology, G. B. Pant Institute of Post Graduate \\ Medical Education and Research (GIPMER), New Delhi, India \\ Address for correspondence Dr. Daljit Singh, MCh, Department of \\ Neurosurgery, G. B. Pant Institute of Post Graduate Medical \\ Education and Research (GIPMER), Room no. 520, Jawaharlal Nehru \\ Marg, New Delhi 110002, India (e-mail: drdaljit@hotmail.com).
}

${ }^{3}$ Department of Gastroenterology, G. B. Pant Institute of Post Graduate Medical Education and Research (GIPMER),

New Delhi, India

Indian J Neurosurg 2016;5:196-201.

\begin{abstract}
Keywords

- peroral extrusion

- ventriculoperitoneal shunt

- gut perforation

Several case reports regarding complications of ventriculoperitoneal (VP) shunt have been published, but peroral extrusion of shunt tube is unusual and reported less frequently. A 4-year-old male child with previous history of VP shunt insertion for congenital hydrocephalus along with shunt revisions twice presented with peritoneal end of shunt tube protruding through the mouth following an acute episode of vomiting. He was conscious without any signs of infection or neurologic deficits. The distal portion of the tube was removed uneventfully with the help of upper GI endoscope that, in addition to removal, provided better views for the identification of site and size of perforation. Peroral extrusion of the shunt tube needs immediate treatment that includes removal of extruded shunt tube, treatment of underlying infection, and attention to perforated viscus. We review the possible pathogenesis of this entity and various treatment options.
\end{abstract}

\section{Introduction}

It has been reported that in ventriculoperitoneal (VP) shunt insertion, complication rates range between 24 and $47 \%$ of which abdominal complications account for approximately $25 \%{ }^{2}$ Bowel perforation as a complication of VP shunt is reported to occur between 0.1 and $0.7 \%$, and may lead to significant mortality and morbidity caused by peritonitis or meningoencephlitis. ${ }^{3}$

After gut perforation, the shunt tube may present at one of the natural orifices, of which peranal extrusion is more common. ${ }^{2}$ Sigmoid is the most frequent site of gastrointestinal (GI) perforation followed by transverse colon and stomach. ${ }^{4}$ Here we report an unusual case of peroral extrusion of the peritoneal shunt tube in a 4-year-old male child as a delayed complication of VP shunt insertion.

received

February 5, 2016

accepted

March 11, 2016

published online

November 2, 2016
DOI http://dx.doi.org/ $10.1055 / \mathrm{s}-0036-1584586$ ISSN 2277-954X.

\section{Case Report}

A 4-year-male child presented with extrusion of distal end of shunt tube from the mouth after an episode of projectile vomiting without abdominal pain. The child was full-term born with delayed milestones, a known case of congenital hydrocephalus who had history of being operated for VP shunt at age of 1 year followed by abdominal end revision 6 months later, and at the age of 3 years a left VP shunt revision was done and the old shunt tube was removed. The length of protruded shunt tube was approximately $10 \mathrm{~cm}$ from the incisors with no visible cerebrospinal fluid (CSF) flow at tip (-Fig. 1A). The child was afebrile, clinically well, and alert without any signs of peritonitis, without clinical evidence of meningitis, neck rigidity, or signs of increased intracranial pressure. Routine laboratory investigations
License terms

$\circledast(1) \Theta \circledast$ (c) 2016 Neurological Surgeons' Society of India 


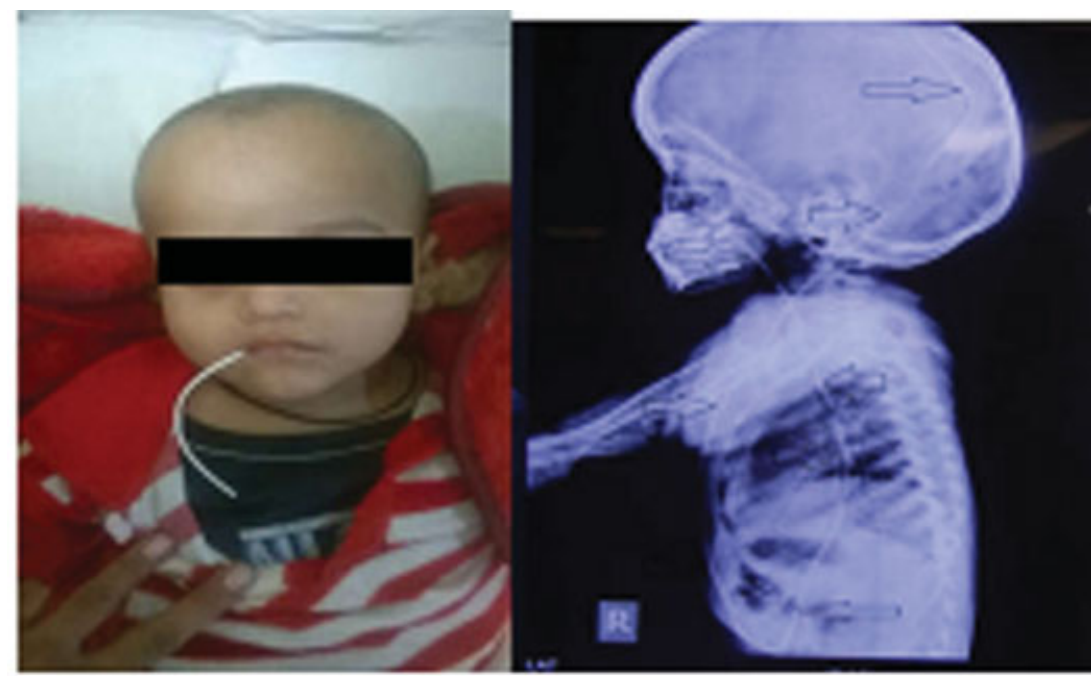

A

C

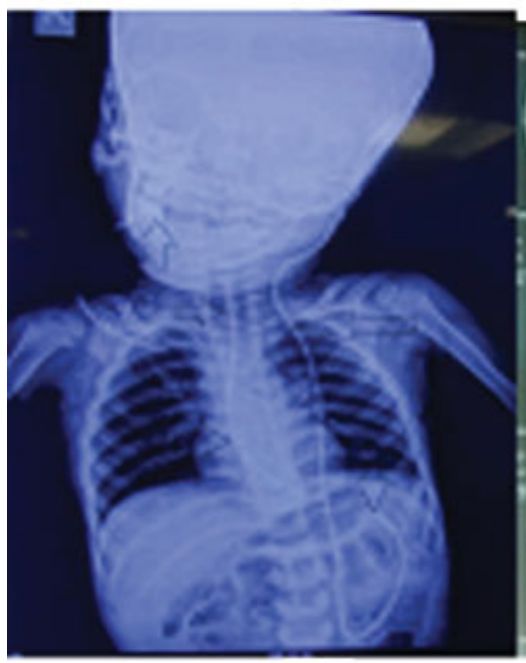

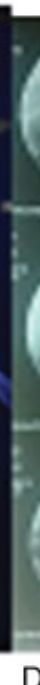

B

D

Fig. 1 (A). Per oral extrusion of distal end of VP shunt tube. (B and C) Anteroposterior and lateral X-rays showing route of shunt tube and ascending through esophagus and coming out from oral cavity. (D) Barium meal series 3 days after endoscopic removal suggestive of absence of spillage from stomach rent.

turned out to be normal. Shunt series depicted shunt tube ascending through the esophagus and protruding through mouth (-Fig. 1B, C). Ultrasound of the abdomen was normal. Computed tomography (CT) of the brain revealed optimally placed ventricular tip of shunt tube inside the normal-sized left lateral ventricle with resolution of previous hydrocephalus.

Prophylactic parenteral antibiotics were initiated and the patient was subjected to upper GI endoscopy, where the shunt tube was seen entering the stomach through rent on the greater curvature (-Fig. 2A). The shunt tube was cut near the rent with the help of endoscopic scissors (-Fig. 2B), the proximal end slipped into the peritoneal cavity

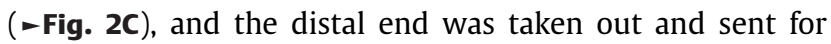
microbiologic examination. The rent in the stomach was small $(<1 \mathrm{~cm})$ with smooth margins ( - Fig. 2D). Hence the rent was not closed. The cranial incision was opened, shunt tube disconnected below the chamber, and both the ventricular and abdominal ends were removed through this incision. The patient was kept on continuous nasogastric aspiration and nil orally for 2 days. On third day barium meal showed no spillage of barium into the cavity (-Fig. 1D).

Meanwhile the CSF collected from the chamber was found to be sterile on culture examination. Cytology revealed no cells, and biochemistry values were within normal limits. On microbiologic examination of the extruded shunt tube, the culture grew colonies of Enterobacter spp. However, the patient remained asymptomatic without any episodes of fever or features of meningitis till 14 days after which he was discharged. He had been on regular follow-up for 3 months and had no complaints.

\section{Discussion}

Among reported cases of VP shunt-induced gut perforations, the colon (70\%) forms the most common site, followed by the stomach (16\%) and small bowel (14\%). ${ }^{5}$ The incidence of perforation is inversely related to the mobility of gut, and the 


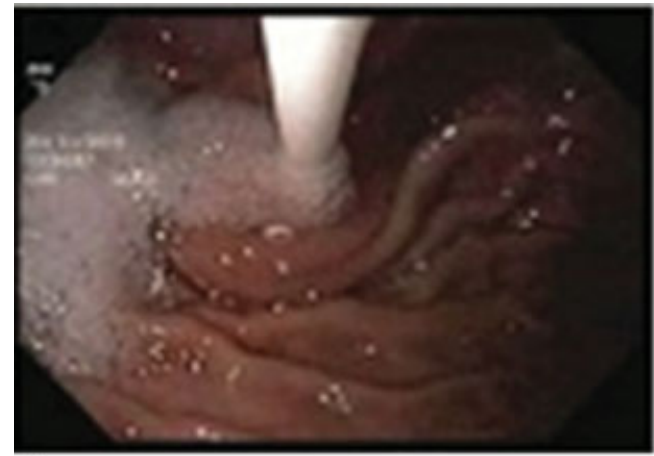

A

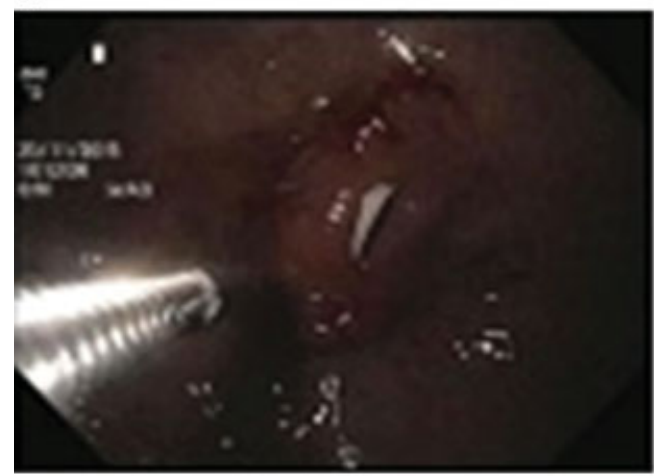

C

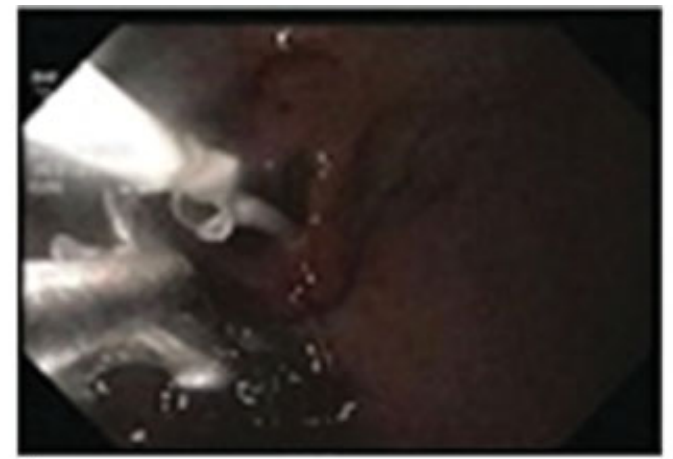

B

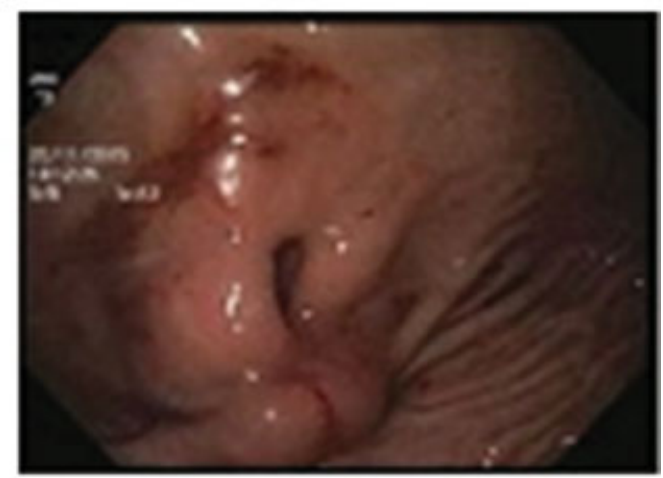

$\mathrm{D}$

Fig. 2 Endoscopic images. (A) Shunt tube entering through a rent on the greater curvature of the stomach. (B) Shunt tube being cut by endoscopic scissors. (C) Retraction of distal end of remaining portion of cut shunt tube seen through rent in the stomach. (D) Rent in the stomach with smooth margins being left to heal on its own.

colon is the most frequently perforated viscus due to its immobility. ${ }^{2}$ According to literature, the shunt tube more commonly extrudes through the anus $(61.9 \%)^{2}$; however, oral extrusion, as in our case, is relatively uncommon with total of approximately 20 cases reported in literature.

Usually these patients, because of infection by an enteric organism, present with features of ventriculitis or meningitis. Patients with proximal perforations involving the stomach or proximal jejunum are less prone to severe infectious complications than those with the distal intestine like colon. ${ }^{6}$ This is in accordance with our case that showed lack of any serious meningeal or peritoneal infection.

The exact pathophysiology of late perforation is difficult to establish. Most cases had a delayed presentation, suggestive of chronic inflammatory process as opposed to traumatic event. ${ }^{7}$ Proposed mechanisms suggest that the tip of the shunt tube adheres to the intestinal wall and erodes it, because of continuous friction at the site of contact. ${ }^{1,8}$ Another is perforation of gut by a chronic irritative process in which the VP shunt adheres to the serosal surface by way of foreign-body reaction, related to silicone allergy., ${ }^{5,8}$ The repeated pressure on the fixed point slowly produces an ulcer and eventually a perforation. In a case reported by Shridhar and Karmarker, ${ }^{6}$ the probable mechanism of bowel perforation was infection, leading to inflammation and adherence of the tube to the proximal gut. A belief says that bowel perforation can be the result of occult shunt infection caused by intraoperative contamination. In our case, chronic irritation by the shunt tube tip to the serosal surface of the stomach might have occurred resulting in perforation. Unlike previously reported cases, our patient has history of revisions twice in past, which might contribute to the above process. Age, male sex, malnutrition, poor general condition, length and type of shunt tube, previous abdominal operation, infection, ${ }^{1}$ and silicone allergy from foreign-body reaction are some of the predisposing factors for bowel perforation. ${ }^{8}$ Weaker intestinal musculature and stronger intestinal peristaltic activity in children contribute to age standing out as major risk factor for perforation. Sharp peritoneal tip or coiled spring-type shunt tubes are more likely to perforate than silicone ones. ${ }^{1,9}$ Predisposing factors in our case included age, male sex, and silicone material of shunt.

Peroral extrusion of VP shunt is rare. ${ }^{10-13}$ The shunt tube is normally propelled distally by peristalsis after perforation of bowel, but to come out from the mouth, it has to move against normal peristalsis and cross the gastroesophageal junction and esophagus. Once perforated and lying in the stomach or the jejunum, the tube may be made to travel into the oral cavity by forceful repeated vomiting and retching. ${ }^{13}$ The forceful episode of vomiting was responsible for antiperistaltic movement of the shunt tube and its extrusion from the mouth in our case. Gut perforation and shunt tube extrusion can be associated with very high mortality and do not always have a benign course. ${ }^{14}$ High suspicion is needed to diagnose bowel perforation, as less than $25 \%$ of patients with bowel perforation exhibit signs of 
peritonitis. ${ }^{15}$ Prolonged diarrhea with abdominal symptoms in a patient with VP shunt should warn of a possible perforation. CSF cultures have been found to be positive in 23 of 45 patients with bowel perforation, with Escherichia coli being the most common organism. ${ }^{15}$

There are various ways of managing such cases. A summary of some selected cases has been tabulated (-Table 1). The management principles (-Fig. 3) of such complications include diagnosis and treatment of CSF infection or shunt tract inflammation, removal of extruding shunt tubing, and attention to perforated viscus. ${ }^{3}$ Broad-spectrum antibiotics are initiated early. There are multiple ways to remove distal shunt tube in peroral extrusion of VP shunt. A major laparotomy is probably unnecessary as the opening in the bowel is small and seals off spontaneously. ${ }^{1}$ The extruded peritoneal end can be removed through cranial incision by pulling in a retrograde manner. In this method there is always a theoretical risk of infection as the peritoneal end is exposed to atmosphere and the contaminated gut, as seen in the report by Kothari et al. ${ }^{12}$ In another method through cranial incision, both ends are disconnected. The ventricular end is removed through incision, and peritoneal end through the mouth by gentle pull, reducing chances of infection due to lack of contact of contaminated tube to the peritoneum or shunt tract. ${ }^{7}$ Laparoscopy alone or endoscopy assisted has also emerged as a means of removing the shunt tube under visual guidance and also enables inspection of entire peritoneal cavity. Endoscopic removal in our case enabled us to visualize the entry point and rule out any associated damage to the stomach, in addition to minimizing invasiveness and its associated morbidities.

Table 1 Summary of previously reported cases

\begin{tabular}{|c|c|c|c|c|c|c|c|}
\hline \multirow{2}{*}{$\begin{array}{l}\text { Reference } \\
\text { and year }\end{array}$} & \multirow[t]{2}{*}{ Sex } & \multirow[t]{2}{*}{ Age } & \multirow{2}{*}{$\begin{array}{l}\text { CSF } \\
\text { INF }\end{array}$} & \multirow{2}{*}{$\begin{array}{l}\text { Perforated } \\
\text { viscus }\end{array}$} & \multicolumn{3}{|l|}{ Management } \\
\hline & & & & & Division & Proximal end & Distal end \\
\hline Park et al ${ }^{1} 2000$ & $\mathrm{~F}$ & $5 y$ & $\mathrm{~N}$ & Stomach & $\begin{array}{l}\text { The peritoneal } \\
\text { catheter was cut at } \\
\text { the chest }\end{array}$ & $\begin{array}{l}\text { Externalized at the } \\
\text { chest }\end{array}$ & $\begin{array}{l}\text { Removed } \\
\text { endoscopically }\end{array}$ \\
\hline Low et $\mathrm{al}^{2} 2010$ & $M$ & $1 \mathrm{y}$ & NA & Stomach & & $\begin{array}{l}\text { Ventricular catheter } \\
\text { externalized }\end{array}$ & $\begin{array}{l}\text { Peritoneal catheter } \\
\text { removal not } \\
\text { explained }\end{array}$ \\
\hline Odebode $^{5} 2007$ & $\mathrm{M}$ & $15 \mathrm{mo}$ & $\mathrm{N}$ & Jejunum & $\begin{array}{l}\text { Laparotomy, division } \\
\text { of tube flush to } \\
\text { jejunum }\end{array}$ & $\begin{array}{l}\text { Removed via } \\
\text { postauricular incision }\end{array}$ & $\begin{array}{l}\text { Removal PO of distal } \\
\text { portion }\end{array}$ \\
\hline $\begin{array}{l}\text { Sridhar and } \\
\text { Karmarker }^{6} 2009\end{array}$ & $\mathrm{~F}$ & $8 \mathrm{mo}$ & $\mathrm{N}$ & $\mathrm{NA}$ & $\begin{array}{l}\text { Cranial incision and } \\
\text { division of the shunt } \\
\text { below the chamber }\end{array}$ & $\begin{array}{l}\text { Ventricular catheter } \\
\text { removed via cranial } \\
\text { incision }\end{array}$ & $\begin{array}{l}\text { Removal PO of distal } \\
\text { portion }\end{array}$ \\
\hline $\begin{array}{l}\text { Agarwal } \\
\text { et al } 2011\end{array}$ & $\mathrm{M}$ & $1 \mathrm{y}$ & $\mathrm{N}$ & Stomach & $\begin{array}{l}\text { VP shunt was divided } \\
\text { distal to valve via } \\
\text { post auricular } \\
\text { incision }\end{array}$ & $\begin{array}{l}\text { Ventricular catheter } \\
\text { removed via } \\
\text { postauricular } \\
\text { incision. }\end{array}$ & $\begin{array}{l}\text { Peritoneal catheter } \\
\text { removed PO }\end{array}$ \\
\hline $\begin{array}{l}\text { Grifith } \\
\text { et } \mathrm{al}^{10} 1987\end{array}$ & $\mathrm{~F}$ & $9.5 \mathrm{y}$ & $\mathrm{Y}$ & Stomach & & Exteriorized & NA \\
\hline $\begin{array}{l}\text { Fermin } \\
\text { et al }{ }^{11} 1996\end{array}$ & $\mathrm{~F}$ & $15 \mathrm{mo}$ & $\mathrm{N}$ & $\begin{array}{l}\text { Diaphragm } \\
\text { and } \\
\text { trachea }\end{array}$ & $\begin{array}{l}\text { Exploratory } \\
\text { laparotomy, and } \\
\text { revision of VP shunt }\end{array}$ & & Removed PO \\
\hline $\begin{array}{l}\text { Kothari et al } \\
2006\end{array}$ & $\mathrm{~F}$ & $18 \mathrm{mo}$ & NA & NA & At post auricular site & $\begin{array}{l}\text { Removed via } \\
\text { postauricular incision }\end{array}$ & $\begin{array}{l}\text { Removed via } \\
\text { postauricular incision }\end{array}$ \\
\hline $\begin{array}{l}\text { Murali and } \\
\text { Ravikumar }^{13} 2008\end{array}$ & $\mathrm{M}$ & $6 y$ & $\mathrm{~N}$ & Stomach & $\begin{array}{l}\text { Incision in chest with } \\
\text { division of peritoneal } \\
\text { catheter }\end{array}$ & $\begin{array}{l}\text { Proximal portion } \\
\text { connected to a } \\
\text { closed drainage } \\
\text { system }\end{array}$ & $\begin{array}{l}\text { Removal PO of distal } \\
\text { portion }\end{array}$ \\
\hline $\begin{array}{l}\text { Gupta } \\
\text { et } \mathrm{al}^{14} 2012\end{array}$ & M & $4 y$ & NA & Stomach & $\begin{array}{l}\text { VP shunt was divided } \\
\text { distal to valve via } \\
\text { post-auricular } \\
\text { incision }\end{array}$ & $\begin{array}{l}\text { Via postauricular } \\
\text { incision }\end{array}$ & $\begin{array}{l}\text { Via postauricular } \\
\text { incision }\end{array}$ \\
\hline Present case & $\mathrm{M}$ & $4 y$ & $\mathrm{~N}$ & Stomach & $\begin{array}{l}\text { Endoscopic division } \\
\text { of shunt in stomach } \\
\text { near rent in stomach }\end{array}$ & $\begin{array}{l}\text { Via postauricular } \\
\text { incision }\end{array}$ & $\begin{array}{l}\text { Via postauricular } \\
\text { incision and } \\
\text { endoscopically PO }\end{array}$ \\
\hline
\end{tabular}

Abbreviations: CSF, cerebrospinal fluid; F, female; INF, infection; M, male; N, no; NA, not available; PO, per orally; Y, yes. 


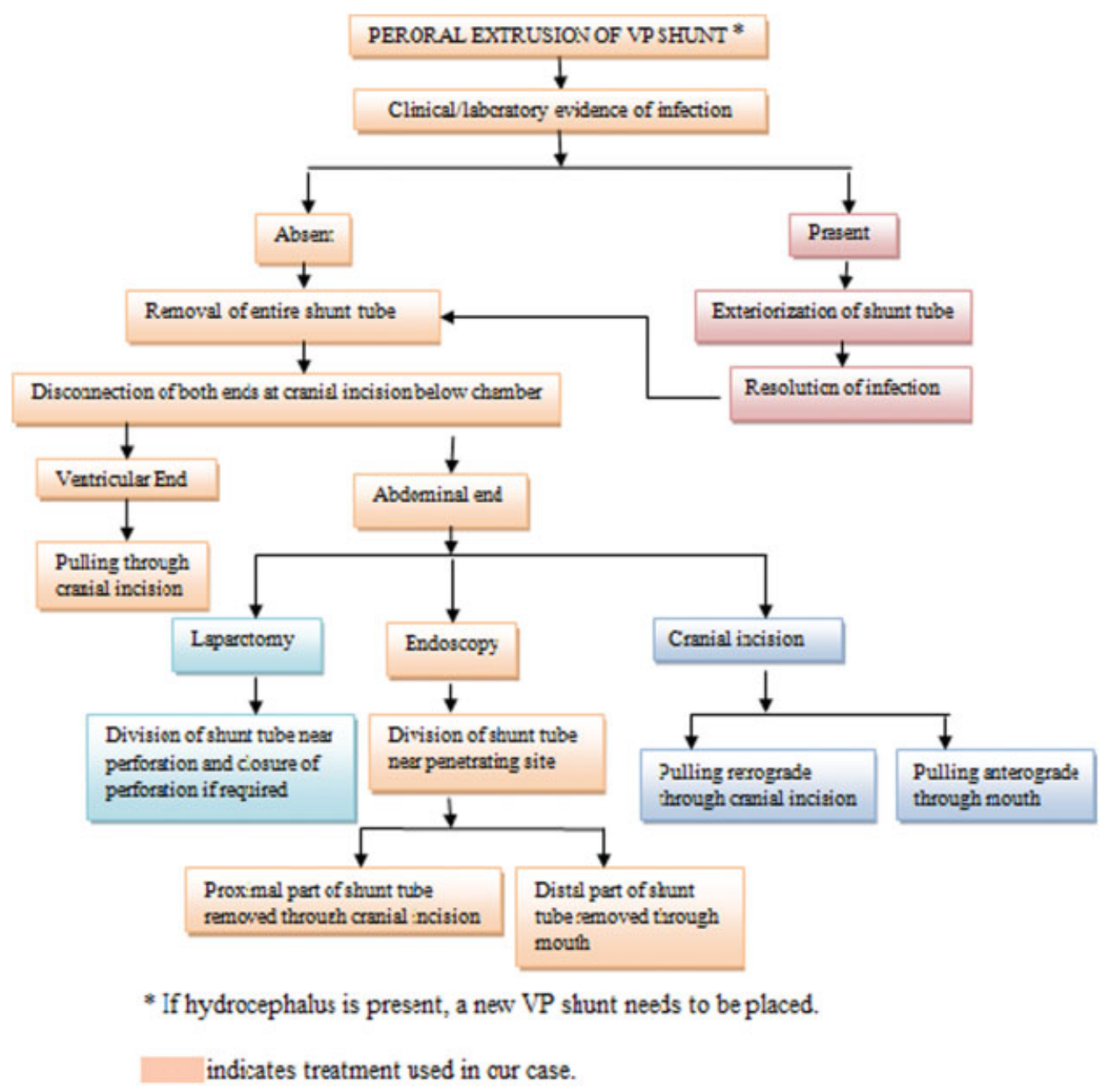

Fig. 3 Flow chart depicting various management options for treatment of peroral extrusion of ventriculoperitoneal (VP) shunt.

\section{Conclusion}

The appearance of shunt tube in the mouth represents gut penetration. Spontaneous penetration or perforation is a rare complication and a high index of suspicion is essential to diagnose it, particularly in pediatric patients, as the abdominal symptoms and signs may be vague. Abdominal $\mathrm{X}$-rays and CT may be required and CSF culture is mandatory for diagnosis of retrograde CSF infection. Endoscopic removal of shunt tube is advocated and laparotomy is not required in the absence of infection or intra-abdominal complications to avoid major operative procedures related to morbidity and mortality.

Source of Support

None.

\section{Conflict of Interest}

None.

\section{References}

1 Park CK, Wang KC, Seo JK, Cho BK. Transoral protrusion of a peritoneal catheter: a case report and literature review. Childs Nerv Syst 2000;16(3):184-189

2 Low SW, Sein L, Yeo TT, Chou N. Migration of the abdominal catheter of a ventriculoperitoneal shunt into the mouth: a rare presentation. Malays J Med Sci 2010;17(3):64-67

3 Mandhan P, Wong M, Samarakkody U. Laparoendoscopic removal of peroral extrusion of a ventriculoperitoneal shunt. Asian J Endosc Surg 2015;8(1):95-97

4 Hai A, Rab AZ, Ghani I, Huda MF, Quadir AQ. Perforation into gut by ventriculoperitoneal shunts: a report of two cases and review of the literature. J Indian Assoc Pediatr Surg 2011;16(1):31-33

5 Odebode TO. Jejunal perforation and peroral extrusion of a peritoneal shunt catheter. Br J Neurosurg 2007;21(2):235-236

6 Sridhar K, Karmarkar V. Peroral extrusion of ventriculoperitoneal shunt: case report and review of literature. Neurol India 2009; 57(3):334-336

7 Agarwal M, Adhana R, Namdev H, Yadav YR, Agrawal T. Transoral extrusion of the ventriculo-peritoneal shunt: a case report and review of literature. J Pediatr Neurosci 2011;6(2):149-151

8 Brownlee JD, Brodkey JS, Schaefer IK. Colonic perforation by ventriculoperitoneal shunt tubing: a case of suspected silicone allergy. Surg Neurol 1998;49(1):21-24 
9 Yilmaz MB, Egemen E, Tonge M, Kaymaz M. Transoral protrusion of a peritoneal catheter due to gastric perforation 10 years after a ventriculoperitoneal shunting: case report and review of the literature. Turk Neurosurg 2013;23(2):285-288

10 Griffith JA, DeFeo D. Peroral extrusion of a ventriculoperitoneal shunt catheter. Neurosurgery 1987;21(2):259-261

11 Fermin S, Fernández-Guerra RA, Sureda PJ. Extrusion of peritoneal catheter through the mouth. Childs Nerv Syst 1996;12(9):553-555

12 Kothari PR, Shankar G, Kulkarni B. Extruded ventriculo-peritoneal shunt: an unusual complication. J Indian Assoc Pediatr Surg 2006; 11(4):255-256
13 Murali R, Ravikumar V. Transoral migration of peritoneal end of ventriculoperitoneal shunt: a case report of a rare complication and review of literature. J Pediatr Neurosci. 2008; 3(2):166-168

14 Gupta M, Digra NC, Sharma N, Goyal S, Agrawal A. Peroral extrusion of the peritoneal catheter in an infant. $\mathrm{N}$ Am J Med Sci 2012;4(6):290-292

15 Sathyanarayana S, Wylen EL, Baskaya MK, Nanda A. Spontaneous bowel perforation after ventriculoperitoneal shunt surgery: case report and a review of 45 cases. Surg Neurol 2000;54(5):388-396 